\title{
Perjanjian Penetapan Harga Dalam Industri Jasa Uang Tambang Kontainer (Freight Container) : Studi Putusan KPPU Nomor 8/KPPU-L/2018
}

\author{
Tadeus Adam Sianturi ${ }^{{ }^{*}}$, Sylvana Murni Deborah Hutabarat ${ }^{2}$ \\ 12 Fakultas Hukum, Universitas Pembangunan Nasional “Veteran” Jakarta \\ *Korespondensi: tadeusadams@gmail.com
}

Info Artikel

Diterima : 29 Jun $2020 \quad$ Direvisi : 14 Jul $2020 \quad$ Disetujui : 7 Ags $2020 \quad$ Diterbitkan : 7 Des 2020

DOI: https://doi.org/10.31599/krtha.v14i2.196

Keywords : $\quad$ Businesss Competition, Price Fixing Agreement, Freight Container

Abstract : In the enforcement of fair business competition law there are still some discrepancies between the facts in the field with the existing rules, one of which can be known through cases decided by KPPU. Where in the KPPU Decision Number 8 / KPPU-L / 2018 concerning Alleged Violations Article 5 Paragraph (1) of Law Number 5 of 1999 concerning Probibition of Monopolistic Practices and Unfair Business Competition in the Freight Container Service Industry on the Surabaya Route to Ambon by 4 Shipping Companies. The objectives of this paper is to learn the form of price fixing agreement made by the shipping company in KPPU Decision Number 8 / KPPU-L / 2018 and providing an understanding of the impact of the pricing agreement seen in KPPU Decision Number 8 / KPPU-L / 2018. The method used in this research is normative juridical research. The conclusions that can be drawn from this study are: First, the four shipping companies in the freight container service industry on the Surabaya route to Ambon have entered into a price-fixing agreement by issuing price adjustment letters, in which one of the evidences used is indirect evidence. Second, the impact that occurred due to price fixing agreements by shipping companies, namely Maluku Province, was the highest contributor to inflation in Indonesia. Where one of the contributors to inflation in the Maluku Province, especially Ambon City comes from the logistics sector.

Kata kunci : Persaingan Usaha, Perjanjian Penetapan Harga, Uang Tambang Kontainer
Abstrak :
Dalam penegakan hukum persaingan usaha yang sehat masih terdapat beberapa ketidaksesuaian antara fakta dilapangan dengan aturan yang ada, salah satunya dapat diketahui melalui kasus yang diputus oleh KPPU. Dimana dalam Putusan KPPU Nomor 8/KPPU-L/2018 tentang Dugaan Pelanggaran Pasal 5 Ayat (1) Undang-Undang Nomor 5 Tahun 1999 tentang Larangan Praktek Monopoli dan Persaingan Usaha Tidak Sehat dalam Industri Jasa Freight Container (Uang Tambang) pada Rute Surabaya Menuju Ambon oleh 4 Perushaan Pelayaran. Tujuan dari penulisan ini untuk mempelajari bentuk perjanjian penetapan harga yang dilakukan oleh perusahaan pelayaran dalam Putusan KPPU Nomor 8/KPPU- $\mathrm{L} / 2018$ serta memberikan pemahaman terhadap dampak dari perjanjian penetapan harga dilihat pada Putusan KPPU Nomor 8/KPPU-L/2018. Metode yang digunakan dalam penelitian ini adalah penelitian yuridis normatif. Kesimpulan yang dapat diambil dari penelitian ini yaitu: Pertama, keempat perusahaan pelayaran dalam industri jasa uang tambang kontainer (freight container) pada rute Surabaya menuju Ambon telah melakukan perjanjian penetapan harga dengan mengeluarkan 
surat penyesuaian harga, dimana salah satu pembuktiannya yang digunakan yaitu bukti tidak langsung. Kedua, dampak yang terjadi akibat perjanjian penetapan harga oleh perusahaan pelayaran yaitu Provinsi Maluku menyumbang inflasi tertinggi di Indonesia. Dimana salah satu penyumbang inflasi yang ada di Provinsi Maluku khususnya Kota Ambon berasal dari sektor logistik.

\section{PENDAHULUAN}

Indonesia merupakan negara yang indah dan berbetuk kepulauan, dimana secara terperinci Indonesia memiliki lebih dari 17 ribu pulau dengan luas total 7,81 juta $\mathrm{Km}^{2}$. Dimana 2,01 juta $\mathrm{Km}^{2}$ merupakan daratan, 3,25 juta $\mathrm{Km}^{2}$ adalah lautan dan sisanya merupakan Zona Ekonomi Eksklusif (ZEE) ${ }^{1}$. Maka dapat ditarik kesimpulan bahwa Indonesia memiliki lautan yang sangat luas.

Maka yang dapat dilakukan untuk menjamin terhubungnya pulau satu dengan pulau lainnya adalah dengan menggunakan berbagai macam alat transportasi. Transportasi merupakan usaha dan kegiatan mengangkut atau membawa barang dan/atau penumpang dari satu tempat ke tempat lainnya ${ }^{2}$. Mulai dari trasnportasi darat, udata, dan laut. Dimana bila menggunakan transportasi darat membutuhkan jembatan yang menghubungkan pulau satu dengan lainnya dan bandara untuk tempat pesawat terbang mendarat dari pulau satu dengan lainnya. Dan terakhir pelabuhan sebagai tempat kapal bersadar dan menhubungkan pulau-pulau melalui jalur laut. Kegunaan transportasi tersebut mulai dari mengantarkan orang dari satu tempat ke tempat lainnya dan juga mengantarkan barang. Dalam hal mengantarkan barang tersebut digunakan sebagai cara dalam menjamin kesejahteraan masyarakat, hal itu dikarenakan bareng yang diantarkan dapat berupa sembako, bahan bangunan, elektronik hingga kendaraan bermotor.

Di dalam peraturan yang ada di Indonesia, kegiatan transportasi laut ini dapat disebut dengan angkutan di perairan. Angkutan di perairan ini dipahami bahwa kegiatan mengangkut dan/atau memindahkan penumpang dan/atau barang menggunakan kapal. ${ }^{3}$ Berdasarkan penjelasan tersebut sangatlah jelas bahwa kapal digunakan untuk mengantarkan sesuatu dari satu titik ke titik yang lain. Namun harus digaris bawahi bahwa tidak semua kapal memiliki keguaan yang dapat mengantarkan orang dan barang secara

\footnotetext{
${ }^{1}$ Elviana Roza, "Maritim Indonesia, Kemewahan Yang Luar Biasa”, http://www2.kkp.go.id/artikel/2233maritim-indonesia-kemewahan-yang-luar-biasa, diakses pada tanggal 17 Februari 2020, pukul 09.51 WIB. ${ }^{2}$ Abdul Kadir, 2006, Transportasi: Peran dan Dampaknya Dalam Pertumbuban Ekonomi Nasional, USU e-Journals, Vol. 1, No. 3, Universitas Sumatra Utara, Medan, hlm. 121

${ }^{3}$ Republik Indonesia, Undang-Undang Republik Indonesia Nomor 17 Tahun 2008 tentang Pelayaran, pasal 1 angka 2.
} 
bersamaan. Secara khusus terdapat kapal yang hanya dapat mengantarkan orang saja dan ada kapal yang ditujukan hanya untuk mengantarkan barang, salah satu kapal tersebut adalah kapal peti kemas.

Kapal peti kemas yang dalam Bahasa inggris containership atau celullarship adalah kapal yang beroprasi hanya untuk mengangkut peti kemas yang standar, dan berongga atau cells yang betujuan untuk menyimpan peti kemas. ${ }^{4}$ Seperti dijelaskan diatas, salah satu kegunaan kapal adalah mengirimkan barang-barang berupa sembako atau barang bangunan tidak hanya diletakan begitu saja di dalam kapal. Hal itu akan mengakibatkan barang-barang tersebt tidak terorganisir dengan baik dan bahkan dapat mengakibatkan kerusakan produk selama proses pengiriman.

Upaya untuk mengatasi permasalahan tersebut dibutuhkan peti kemas. Namun pengelola Ekspedisi Muatan Kapal Laut (EMKL) tidak menyediakan peti kemas kepada konsumen secara cuma-cuma, melaikan harus meyewa kepada penyedia peti kemas atau perushaan jasa uang tambang kontainer (freight container). Hal itu dikarenakan Usaha Ekspedisi Muatan Kapal Laut (EMKL) adalah kegiatan usaha yang mengurusi dokumen dan melaksanakan perkerjaan yang berkaitan dengan penerimaan dan penyerahan muatan yang diangkut melalui laut ${ }^{5}$. Dengan demikian pihak EMKL hanya mengurusi dokumen dan masuk keluarnya petikemas dari dan ke kapal laut. Maka konsumen yang ingin mengirimkan barang-barangnya harus menyewa peti kemas sebelum melakukan pengiriman melalui jalur kapal.

Tentu saja dapat dipahami bahwa dengan proses pengiriman barang melalui kapal dapat mengurangi beban biaya dengan kapasita barang yang dapat dikirim lebih besar ketimbang menggunakan jalur udara maupun darat. Maka terdapat beberapa perusahaan yang bergerak dibidang jasa uang tambang kontainer (freight container) meskipun tidak banyak. Dengan demikian akan terjadi sebuah persaingan antar perushaan demi mendapatkan keuntungan.

Persaingan yang timbul membuat pelaku usaha berusaha untuk mengciptakan, mengemas, serta memasarkan produk yang dimiliki baik barang ataupun jasa sebaik mungkin agar menarik perhatian konsumen. ${ }^{6}$ Dengan adanya persaingan antar pelaku

\footnotetext{
4 "Kapal Peti Kemas" https://id.wikipedia.org/wiki/Kapal peti kemas, diakses tanggal 21 Februari 2020, pukul 17.00 WIB.

${ }^{5}$ Chairil Anwar Pohan, Manajemen Pajak Korporat Kemaritiman: Berbasiskan Konsep dan Strategi Tax Planning, PT. Gramedia Pustaka Utama, Jakarta, 2019, hlm. 91.

${ }^{6}$ Mustafa Kamal Rokan, Hukum Persaingan Usaha (Teori dan Praktiknya di Indonesia),Rajawali Pers, Jakarta, 2010, hlm. 1
} 
usaha, maka akan memberikan dampak positif juga negative kepada konsumen. Dimana dampak positifnya, pelaku usaha yang berlomba mendapatkan hati konsumen dapat melakukannya dengan memberikan produk yang lebih unggul dari pesaingnya dimana konsumen mendapatkan produk dengan kualitas yang terbaik.

Namun dalam hal negatif tersebut akan terjadi bilamana pelaku usaha menjalankan usahanya dengan prilaku negative yang dapat mengakibatkan sistem ekonomi yang tidak kompetitif. Pesaingan dengan prilaku negatif ini akan mengakibatkan terjadinya monopoli dan persaingan usaha tidak sehat. Dimana dapat dipahami bahwa terjadinya monopoli dan persaingan usaha tidak sehat ini ditujukan demi kepentingan pelaku usaha sendiri demi mendapatkan keuntungan setinggi-tingginya dan tidak menghiraukan nasib konsumen.

Demi mengantisipasi terjadinya praktek monopoli dan persaingan usaha tidak sehat oleh pelaku usaha, negara hadir dalam melindungi rakyatnya dengan mengeluarkan undang-undang yang mengatur mengenai itu yang tercantum dalam Undang-Undang Nomor 5 Tahun 1999 tentang Larangan Praktek Monopoli dan Persaingan Usaha Tidak Sehat. Selain dibuatnya undang-undang tersebut, tidak begitu saja praktek monopoli dan persaingan usaha tidak sehat hilang begitu saja dikarenakan pelaku usaha akan mematuhi sepenuhnya. Hal itu dikarenakan selalu ada godaan atau peluang yang mengakibatkan pelaku usaha yang tergoda untuk melakukannya, sehingga dalam hal menegakan sengketa mengenai persaingan usaha, pemerintah membutuhkan sebuah lembaga khusus yang menangani sengketa tersebut. Komisi Pengawas Persaingan Usaha (KPPU) adalah lebaga khusus independen yang menjalankan dan menjamin ditegakannya Undang-Undang Nomor 5 Tahun 1999 tentang Larangan Praktek Monopoli dan Persaingan Usaha Tidak Sehat.

Dalam menjamin tidak terjadinya praktek monopoli dan persaingan usaha tidak sehat, Undang-Undang Nomor 5 Tahun 1999 tentang Larangan Praktek Monopoli dan Persaingan Usaha Tidak Sehat juga menjelaskan secara jelas kegiatan yang sebagian besar dilakukan dalam sebuah transaksi bisnis yakni perjanjian. Perjanjian merupakan salah satu tindakan yang diatur Undang-Undang Nomor 5 Tahun 1999 tentang Larangan Praktek Monopoli dan Persaingan Usaha Tidak Sehat.

Dalam kenyataanya masih banyak pelaku usaha yang melakukan perjanjian yang diatur dalam Undang-Undang Nomor 5 Tahun 1999 tentang Larangan Praktek Monopoli dan Persaingan Usaha Tidak Sehat. Salah satunya adalah perjanjian penetapan harga, dimana pelaku usaha mengadakan perjanjian dengan pesaingnya atau pelaku usaha lain 
yang melakukan perjanjian untuk menetukan suatu harga terhadap barang dan/atau jasa yang mereka perdagangkan kepada kosumen dimana akan menimbulkan suasanya bisnis tanpa persaingan. Hal itu dikarenakan perjanjian seperti itu akan menghilankan persaingan dalam berusaha atas pelaku usaha yang mengadakan atau ikut dalam perjanjian tersebut. ${ }^{7}$

Dengan adanya aturan mengenai penetapan harga tersebut, nyatanya masih ada yang melakukannya. Dalam kasus ini terjadi dalam industri jasa uang tambang kontener (freight container). Dimana pada tahun 2018, KPPU menerima laporan bahwa terjadi dugaan perjanjian penetapan harga yang dilakukan oleh empat pelaku usaha pelayaran yang mengakibatkan terjadinya inflasi di Provinsi Maluku khususnya Kota Ambon dari sector logistik. Hal itu terjadi dikarenakan barang-barang yang ada di Kota Ambon, baik barang sembako ataupun barang kebutuhan lain untuk pembangunan semuanya didatangkan dari Surabaya menggunakan kontainer kapal laut. Perushaan pelayaran yang melayani pengiriman kontainer rute Surabaya menuju Ambon ada 4 perusahaan yaitu PT. Tanto Intim Line, PT. Meratus Line, PT Pelayaran Tempuran Emas, Tbk dan PT. Salam Pasific Indonesia Line. Bahwa PT. Salam Pasific Indoneisa Line (PT. SPIL) merupakan pesaing yang baru masuk dalam rute Surabaya-Ambon. Bahwa keempat perusahaan tersebut membuat surat kenaikan tarif jasa uang tambang kontainer (freight container) pada rentang waktu 23-24 Agustus 2017 dengan format surat yang dikeluarkan oleh empat pelaku usaha tersebut sangat mirip begitu juga dengan substanfsi surat. Berdasarkan putusan KPPU Nomor 8/KPPU-L/2018, keempat pelaku usaha tersebut disangkakan dengan Dugaan adanya pelanggara pasal 5 ayat (1) Undang-Undang Nomor 5 Tahun 1999 tentang Larangan Praktek Monopoli dan Persaingan Usaha Tidak Sehat.

Pada Putusan KPPU Nomor 8/KPPU-L/2018 memutuskan bahwa PT. Tanto Intim Line, PT. Meratus Line, PT Pelayaran Tempuran Emas, Tbk dan PT. Salam Pasific Indonesia Line terbukti secara sah dan menyakinkan melanggar pasal 5 ayat (1) UndangUndang Nomor 5 Tahun 1999 tentang Larangan Praktek Monopoli dan Persaingan Usaha Tidak Sehat.

Berdasarkan hal tersebut rumusan masalah dalam penelitian ini yaitu: Pertama, bagaimana bentuk penetapan harga yang dilakukan oleh pelaku usaha dalam industry jasa uang tambang kontainer (freight container) rute Surabaya menuju Ambon dalam Putusan KPPU Nomor 8/KPPU-L/2018? Kedua, bagaimana dampak perjanjian pentapan harga yang terjadi dalam industry jasa uang tambang kontainer (freight container) dalam Putusan

\footnotetext{
${ }^{7}$ Rachmadi Usman, Hukum Persaingan Usaha Di Indonesia, Gramedia Pustaka Utama, Jakarta, 2004, hlm. 44.
} 
KPPU Nomor 8/KPPU-L/2018? Sehingga penulis tertarik untuk meneliti dan mengkaji permasalahan ini sebagai bentuk karya ilmiah dengan judul "Perjanjian Penetapan Harga Dalam Industri Jasa Uang Tambang Kontainer (Frieght Container) (Studi Putusan KPPU Nomor 8/KPPU-L/2018)"

\section{METODE PENELITIAN}

Dalam kepentingan penulisan ini, tentunya penulis membutuhkan data yang akurat, lengkap dan relevan dengan permasalahan yang telah diuraikan pada bagian sebelumnya, merupakan suatu penelitian yuridis normatif, maka penelitian ini berbasis pada analisa dengan cara pengamatan, pemahaman, dan penghayatan norma hukumJenis Penelitian ini menggunakan metode penelitian kepustakaan yaitu yuridis normatif yang dilakukan dengan cara meneliti bahan pustaka atau bahan sekunder yang akan dikumpulkan serta dianalisa dan diteliti ${ }^{8}$. Penelitian ini mengandung teori-teori yang diperoleh dari bahan pustaka. Pendekatan masalah yang digunakan dalam penelitian ini adalah tipe Case Approach. Pendekatan ini dilakukan dengan melakukan telaah pada kasus-kasus yang berkaitan dengan isu hukum yang dihadapi. Kasus-kasus yang ditelaah merupakan kasus yang telah memperoleh putusan pengadilan berkekuatan hukum tetap.

Dalam penelititan ini, teknik pengumpulan data diperoleh melalui Studi dokumen, yaitu teknik yang digunakan untuk memperoleh informasi dari buku-buku dan bahan tertulis lainnya yang berkaitan dengan penulisan ini. Selain itu pengumpulan data juga dilakukan melalui analisa data yang merupakan kegiatan untuk menentukan isi atau makna hukum yang dijadikan rujukan dalam menyelesaikan permasalahan hukum yang menjadi objek kajian. Dalam hal menganalisis data penulis akan mengumpulkan bahan dari sumber hukum, sumber hukum dan literatur yang terkait dengan persaingan usaha dan persaingan usaha tidak sehat. Penulis juga akan meninjau berdasarkan hasil putusan KPPU Nomor 08/KPPU-L/2018 untuk menjawab rumusan masalah.

\section{PEMBAHASAN}

\section{A. Bentuk Perjanjian Penetapan Harga Pada Jasa Uang Tambang Kontainer Dalam Putusan KPPU Perkara Nomor 8/KPPU-L/2018}

Pada hari Kamis, 23 Mei 2019 Komisi Pengawas Persaingan Usaha telah memutus

\footnotetext{
8 Soerjono Soekanto dan Sri Mamudji, Penelitian Hukum Normatif. Raja Grafindo Persada. Jakarta, 2006,
} hlm 13-14. 
perkara Nomor 8/KPPU-L/2018. Dimana dalam perkara tersebut diduga terjadi perlanggaran Pasal 5 ayat (1) Undang-Undang Nomor 5 Tahun 1999 tentang Larangan Praktek Monopoli dan Persaingan Usaha TIdak Sehat yang mengatur mengenai perjanjian penetapan harga. Hal tersebut terjadi pada Industri Jasa Uang Tambang (Freight Container) pada Rute Surabaya menuju Ambon yang dilakukan oleh 4 perusahaan pelayaran.

Bahwa akibat tindakan pelaku usaha tersebut mengakibatkan Provinsi Maluku menyubang inflasi tertinggi di Indonesia pada bulan November 2017, berdasarkan laporan dari Bank Indonesia Provinsi Maluku dalam rapat Tim Pengendali Inflasi Daerah (TPID) di Provinsi Maluku. Hal tersebut dikarenakan barang-barang yang ada di Kota Ambon, baik barang sembako ataupun barang kebutuhan lain untuk pembangunan semuanya didatangkan dari Surabaya menggunakan kontainer kapal laut. Dan perusahaan pelayaran yang melayani perngiriman kontainer rute Surabaya menuju Ambon adalah 4 perusahaan terlapor.

Tentu saja dalam memutus perkara perjanjian penetapan harga tersebut, Majelis Komisi melakukan pemenuhan unsur-unsur perjanjian penetapan harga dimana pasal 5 ayat (1) Undang-Undang Nomor 5 Tahun 1999 menentukan bahwa "Pelaku usaha dilarang membuat perjanjian dengan pelaku usaha pesaing untuk menetapkan harga atau suatu barang dan atau jasa yang harus dibayarkan oleh konsumen atau pelanggan pada pasar bersangkutan yang sama.”. Dimana pemenuhan unsur pasal pasal 5 ayat (1) UndangUndang Nomor 5 Tahun 1999 yaitu sebagai berikut:

1. Unsur Pelaku Usaha, dimana dalam Pasal 1 angka 5 Undang-Undang Nomor 5 Tahun 1999 dapat dipahami bahwa perlaku usaha merupakan orang perorangan atau badan usaha yang berbentuk badan hukum atau tidak dimana melakukan kegiatan usaha dalam bidang ekonomi dalam wilayah hukum Indonesia yang dilakukan secara sendiri ataupun bersama-sama melalui suatu perjanjian. Dengan demikian dapat dipahami bahwa dalam industri jasa uang tambang (freight container) pada rute Surabaya menuju Ambon terdapat 4 perusahaan, yakni: PT Tanto Intim Line, PT Pelayaran Tempuran Emas Tbk, PT Meratus Line, dan PT Salam Pasific Indonesia Lines.

2. Unsur Konsumen, dapat dipahami bahwa menurut Pasal 1 angka 15 UndangUndang Nomor 5 Tahun 1999 yang pada intinya menjelasakan bahwa konsumen merupakan pengguna dan atau pemakai barang dan jasa untuk kegunaannya sendiri atau pihak lain. Dengan begitu konsunem dalam industri jasa uang tambang (freight container) merupakan konsumen yang menginginkan untuk 
mengirim barang dari Surabaya menuju Ambon dengan cara menggunakan jasa yang diberikan oleh pelaku usaha dalam industri tersebut yakni pengiriman menggunakan kapal peti kemas.

3. Unsur Jasa, menurut Pasal 1 angka 17 Undang-Undang Nomor 5 Tahun 1999 meberikan pemahaman "Jasa adalah setiap layanan yang berbentuk perkerjaan atau prestasi yang diperdagangkan dalam masyarakat untuk dimanfaatkan oleh konsumen atau pelaku usaha.”. Maka berdasarkan uraian pasal tersebut, jasa dalam industri uang tambang kontainer ini merupakan jasa pengiriman barang melalui jalur laut menggunakan kapal peti kemas yang dimiliki oleh keempat perusahaan pelayaran.

4. Unsur Pasar Bersangkutan, Pasal 1 angka 10 Undang-Undang Nomor 5 Tahun 1999 memberikan definisi pasar bersangkutan yaitu "Pasar yang berkaitan dengan jangkauan atau daerah pemasaran tertentu oleh pelaku usaha atau barang dan jasa yang sama atau sejenis atau subsitusi dari barang dan atau jasa tertentu.". Bila dilihat dari isi pasal tersebut dapat dipahami bahwa pasar bersangkutan dalam industri jasa uang tambang ini merupakan industri yang memberikan produk berupa jasa uang tambang kontainer (freight container) yang terjadi pada rute Surabaya menuju Ambon yang menunjukan lokasi pasar tersebut terjadi.

5. Unsur Menetapkan Harga, dapat dipahami bahwa bukti surat penyesuaian tarif yang dikeluarkan oleh empat perusahaan pelayaran dalam industri jasa uang tambang kontainer (freight container) merupakan acuan harga yang harus dibayar oleh konsumen menunjukan adanya harga yang telah ditetapkan. Meskipun dalam fakta persindangan, keempat perusahaan tersebut mengatakan bahwa harga yang telah tercantum tidak pernah terrealisasi dikareanakan harga yang terjadi berdasarkan negosiasi. Menurut pedoman pasal 5 Undang-Undang Nomor 5 Tahun 1999 yang dikeluarkan oleh KPPU yang menjabarkan secara umum bentuk-bentuk penetapan harga yang salah satunya adalah kesepakatan menggunakan harga yang seragam sebagai langkah awal untuk negosiasi. ${ }^{9}$

6. Unsur Perjanjian, dapat dipahami bahwa dalam hukum pesaingan usaha perjanjian tidak hanya dilihat dari komunikasinya melainkan perlu juga dilihat dari perilaku masing-masing pelaku usaha. Dimana apakah tindakan mereka independen atau jutsru ada perilaku interdepenedensi antar pelaku usaha yang sewajarnya bersaing,

${ }^{9}$ Peraturan Komisi Pengawas Persaingan Usaha Nomor 4 Tahun 2011 tentang Pedoman Pasal 5 (Penetapan Harga) Undang-Undang Nomor 5 Tahun 1999 tentang Larangan Praktek Monopoli dan Persaingan Usaha Tidak Sehat, hlm 14. 
maka sepatutunya diduga adanya perjanjian penetapan harga. Dalam UndangUndang Nomor 5 Tahun 1999 juga menjelaskan bahwa "Perjanjian adalah suatu perbuatan satu atau lebih pelaku usaha untuk mengikatkan diri terhadap satu atau lebih pelaku usaha lain dengan nama apapun, baik tertulis maupun tidak tertulis". ${ }^{10}$ Dengan demikian penebitan surat penyesuaian tarif uang tambang atau Freight container yang dikeluarkan oleh masing-masing Terlapor adalah bentuk komunikasi dan perilaku Terlapor untuk ikut serta dalam perjanjian penetapan harga.

Bahwa dalam perkembangannya, penegakan perkara persaingan usaha baik di Indonesia maupun di berbagai belahan dunia mengalami kendala bila terpaku pada buktibukti langsung (hard evidence). Dalam hal penegakkan persaingan usaha di Indonesia KPPU tidak memiliki wewenang untuk menyita surat-surat dan melakukan penggeledahaan pelaku usaha yang menjadi kendala dalam mendapatkan pembuktia terutama bukti langsung. Dan juga keberadaan lembaga pengawas persaingan usaha menjadi faktor yang dipikirkan pelaku usaha untuk membuat sebuat perjanjian penetapan harga secara langsung. ${ }^{11}$ Maka Komisi Pengawas Persaingan Usaha (KPPU) mengeluarkan kebijakan yakni Peraturan KPPU Nomor 4 Tahun 2011 tentang Pedoman Pasal 5 Undang-Undang Nomor 5 Tahun 1999 dimana peraturan tersebut menjelaskan dengan jelas perkara perjanjian penetapan harga, serta mengenai bukti langsung (hard evidence) dan bukti tidak langsung (circumstantial evidence). ${ }^{12}$ Dengan demikian keberadaan pembuktian menggunakan bukti-bukti tidak langsung (circumstantial evidence) sebagai bukti petunjuk dapat membantu menerangkan sebuat kasus persaingan usaha.

Tentu saja dalam pembuktian dalam persindangan KPPU Perkara Nomor 8/KPPUL/2018 terlapor berdalil tidak melakukan sebuah perjanjian penetapan harga tertulis dengan pelaku usaha pesaingnya. Para Terlapor berpendapat bahwa surat penyesuaian tarif bukan suatu bentuk perjanjian penetapan harga. Secara umum para terlapor tidak sependapat bahwa surat penyeseuaian tarif (harga) bukanlah bentuk perjanjian

10 Republik Indonesia, Undang-Undang Nomor 5 Tahun 1999 tentang Larangan Praktek Monopoli dan Pesaingan Usaha Tidak Sehat, Pasal 1 angka 7

11 Susanti Adi Nugroho, Hukum Persaingan Usaha di Indonesia: Dalam Teori dan Praktek Serta Penerapan Hukumnya, Jakarta: Kencana Prenada Media Group, 2014, hlm 607.

12 Ningrum Natasya Sirait, Magmul Siregar dan Marlina Deborah Sihaloho, 2019, Penetapan Harga (Price Fixing) Sebagai Perjanjian yang Dilarang Dalam Undang-Undangn Nomor 5 Tabun 1999 Tentang Larangan Praktek. Monopoli dan Persaingan Usaha Tidak Sehat (Studi Putusan KPPU Nomor 2/KPPU-I/2016 tentang Dugaan Price Handling oleh PT. Artha Samudra Kotindo dan PT. Sarana Gemilang), Transparency: E-Journal of Economic Law, Vol. 1, No. 1, Universitas Sumatra Utara, Medan, hlm. 8. 
dikarenakan tidak mencantumkan kesepakatan atau melakukan tanda tangan persetujuan dengan pelaku usaha lain dalam mengeluarkan surat tersebut.

Majelis Komisi juga berpendapat bahwa perjanjian dalam hukum persaingan usaha tidak semata dilihat dari komunikasi antar pelaku usaha, melainkan perlu juga melihat dari perilaku pelaku usaha. Apakah prilaku atau tindakan pelaku usaha tersebut murni kehendak sendiri atau independen, atau justru ada prilaku interdependensi antar pelaku usaha yang semestinya mekera bersaing. Dengan demikian patut diduga bahwa ada perjanjian yang dilakukan oleh pelaku usaha tersebut. ${ }^{13}$

Maka dengan melihat dari pemahaman tersebut, perlu dilihat perilaku-perilaku pelaku usaha sehingga dapat diduga terdapat perjanjian. Bahwa fakta dalam persidangan, keempat terlapor telah mengeluarkan surat penyesuaian tarif freight container rute Surabaya menuju Ambon yang hampir serupa. Baik dalam besaran biaya yang dikenakan konsumen, tanggal dikeluakannya surat tersebut dan tanggal berlaku efektifnya surat tersebut. Dimana dalam hal harga yang dikenakan kepada konsumen, PT Tanto Intim Line, PT Pelayaran Tempuran Emas, Tbk., dan PT. Salam Pasific Indonesia menetapkan tarif Rp. 9.000.000,00 untuk kontainer ukuran 20' sedangkan PT Meratus Line menetapkan tariff Rp. 9.200.000,00 untuk ukuran yang sama. Dan dalam hal tanggal dikeluarkannya surat tersebut PT Tanto Intim Line dikeluarkan tanggal 24 Agustus 2017, dan Terlapor lainnya mengeluarkan surat penetapan tarif tersebut pada tanggal 23 Agustus 2017. Dan tanggal berlaku efektifnya surat yang dibuat keempat terlapor sama, yaitu tanggal 4 September $2017 . .^{14}$

Berdasarkan keterangan para Terlapor, alasan dikeluarkannya surat penyesuaian tarif Freight Container oleh para Terlapor dikarenakan harga freight container rute Surabaya menuju Ambon yang jauh dibawah production cost dimana hal tersebut terjadi karena perusahaan melakukan perang tarif dengan para pesaing sehingga perusahaan mengalami kerugian selama bertahun-tahun. Dapat dipahami bahwa biaya produksi (production cost) merupakan sesuatu yang dikorbankan pelaku usaha dalam proses produksi yang bertujuan menghasilkan produk ${ }^{15}$, dimana dalam hal ini biaya produksi yang ada dapat meliputi bahan bakar kapal, tarif Pelindo, dan tarif buruh yang menghasilkan produk berupa jasa

\footnotetext{
13 Putusan KPPU Nomor 8/KPPU-L/2018 tentang Dugaan Pelanggaran Pasal 5 Ayat (1) Undang-Undang Nomor 5 Tahun 1999 tentang Larangan Praktek Monopoli dan Persaingan Usaha Tidak Sehat dalam Industri Jasa Frieght Container (Uang Tambang) pada Rute Surabaya Menuju Ambon oleh 4 Perusahaan Pelayaran, Jakarta: KPPU, hlm 552.

${ }^{14}$ Ibid., hlm. 542

15 T. Gilarso, Pengantar Ilmu Ekonomi Mikro, Edisi Revisi, Yogyakarta: Kanisius, 2003 Hlm. 125.
} 
uang tambang kontainer (freight container). Sehingga setelah dikeluarkannya surat penyesuaian tarif tersebut, dalam persidangan ditunjukan grafik pergerakan harga konsumen/EMKL keempat perusahaan pelayaran mulai dari Januari 2017 hingga Februari 2018. Dimana dalam grafik tersebut menunjukan bahwa pergerakan harga konsumen para terlapor mengalami kenaikan yang cukup signifikan. ${ }^{16}$

Selain adanya kesamaan prilaku dalam pengeluaran surat penyesuaian tarif Freight Container, para terlapor memiliki kesamaan prilaku bisnis yang diataranya:

1. Terdapat kesamaan dengan merubah strategi bisnis dimana terlapor membuat terminal hub atau transshipment hub melalui pelabuhan Makassar guna mengsiasati cost production yang besar untuk rute Surabaya menuju Ambon.

2. Dan dalam kesamaan prilaku lainnya yaitu kesamaan dalam menjadikan tindakan pelaku usaha pesaing dimana mereka menaikan harga tarif Freight Container sebagai momentum mereka untuk menaikan harga juga. Hal tersebut terjadi karena adanya kesadaran untuk saling menyesuaikan herga satu sama lain agar meraka tidak kehilangan konsumen.

3. Para Terlapor juga memiliki kesamaan harga yang terbentuk di pasar. Dimana sebelum dikeluarkannya surat penyesuaian tarif Freight Container harga pasarannya berada di kisaran Rp3.500.000,00 (Tiga Juta Lima Ratus Ribu Rupiah) Rp4.000.000,00 (Empat Juta Rupiah). Setalah dikeluarkannya surat penyesian tarif freight container dimana harga yang tercantum berada di kisaran Rp9.000.000,00 (Sebilan Juta Rupiah) untuk kontainer ukuran 20’ dan Rp18.000.000,00 (Delapan Belas Juta Rupiah) untuk ukuran 40’.

4. Kesaman pada prilaku penyesuaian tarif yang dilakukan para Terlapor dimana, harga yang terbentuk tidak sebesar harga dalam Surat Penyesuaian Tarif melaikan merupakan hasil negosiasi dengan pihak EMKL dalam hal ini konsumen. Selain itu perbedaan perlakuan khusus terjadi bila relasi EMKL loyal kepada pelaku usaha dengan demikian relasi EMKL mendapatkan promo harga yang lebih murah. Sehingga hal tersebut yang membedakan harga pada tiap-tiap EMKL. ${ }^{17}$

Dalam hal pembuktian perkara yang sebelumnya sudah disampaikan diatas, dalam hal ini sulit ditemukannya bukti langsung (Hard evidence) yaitu sebuah perjanjian yang menunjukan secara jelas bahwa para Telapor mengikatkan diri dengan pelaku usaha

\footnotetext{
${ }^{16}$ Putusan KPPU Nomor 8/KPPU-L/2018, Op.Cit. hlm. 540
}

${ }^{17}$ Ibid., hlm. 542 
pesaing untuk membuat perjanjian penetapan harga. Sehingga diperlukannya bukti tidak langsung (Circumstantial evidence) sebagai bukti petunjuk dimana bukti tidak langsung dapat berupa bukti komunikasi (dimana tidak secara langsung menyampaikan kesepakatan), dan bukti ekonomi. Untuk bukti ekonomi dapat dibagi menjadi bukti perilaku dan bukti struktur. ${ }^{18}$ Setelah melihat dari perilaku pelaku usaha, perlu melihat dari struktur pasar dipahami bahwa strategi bisnis dalam industri ini berada dalam struktur pasar oligopoli. Dalam struktur pasar oligopoli terdiri dari beberapa pelaku usaha yang cenderung sedikit, dimana tidakan yang dilakukan oleh salah satu pelaku usaha sangatlah diperhitungkan oleh rivalnya atau pelaku usaha pesaingnya. Dan karakteristik penting yang timbul dalam pasar oligopoly adalah saling tergantung (interdependent) dari berbagai tindakan dari penjual atau pelaku usaha. ${ }^{19}$ Sehingga dengan adanya sifat saling ketergantungan tersebut perusahaan dalam industry jasa uang tambang kontainer atau freight container saling bergantung tidak hanya terkait dengan harga tetapi juga rute pelayaran.

Selain itu dalam pasar oligopoli para pelaku usaha selalu bersaing, dimana persaingan yang terjadi dapat berupa persaingan harga atau produk. Dalam hal ini para pelaku usaha bersaing dalam harga jasa uang tambang kontainer atau freight container. ${ }^{20}$ Sehingga respon jika ingin mendapatkan keuntungan, ketika ada pelaku usaha yang lari dari harga marginal maka pelaku usaha akan sebisa mungkin menahan atau menaikan atau menurunkan sedikit dari harga marginal. Tindakan tersebut bertujuan untuk menarik konsumen dari pelaku usaha yang harganya jauh lari dari harga marjinal. Hal tersebut terjadi dikarenakan dalam pasar oligopoli, produk dan/atau jasa yang diberikan umumnya bersifat homogen atau derajat terdiferensiasinya rendah. Dengan demikian pelaku usaha tidak dapat memberikan opsi produk berbeda yang diberikan kepada konsumen. Sehingga konsumen sangatlah sensitif dengan perubahan atau perbedaan harga yang terjadi dipasar, dan bila ada pelaku usaha yang harganya jauh melebihin harga dipasaran konsumen akan beralih ke pelaku usaha lain yang memiliki harga yang lebih rendah.

Selain dalam hal struktur pasar tersebut, perlu diketahui bahwa PT Salam Pasific Indonesia Lines atau dalam putusan adalah Terlapor 4, merupakan perusahaan yang baru masuk dalam pasar jasa Freight Container Rute Surabaya menuju Ambon pada Juli 2017 dengan harga freight container sebesar Rp.4.000.000,00 (Empat Juta Rupiah). ${ }^{21}$ Berdasarkan

\footnotetext{
18 Asmah, Hukum Persaingan Usaha "Hakikat Fungsi KPPU di Indonesia”,Makassar: CV.Social Politic Genius (SIGn),2017,hlm.154

${ }^{19}$ Iksan Semaoen dan Siti Mariyatul Kiptiyah, Mikroekonomi, Malang: Universitas Brawijaya Press (UB Press), 2011, hlm. 283.

${ }^{20}$ Eeng Ahman, Membina Kompetensi Ekonomi, Bandung: Grafindo Media Pratama,2017.Hlm 96

${ }^{21}$ Putusan KPPU Nomor 8/KPPU-L/2018, Op.Cit., hlm. 141
} 
keterangan para Terlapor, alasan dikeluarkannya surat penyesuaian tarif dikarenakan harga freight container rute Surabaya menuju Ambon yang jauh dibawah production cost dimana hal tersebut terjadi karena perang tarif yang mengakibatkan kerugian dan momentum pergerakan harga yang diberikan oleh perusahaan pesaing. Dengan masuknya suatu perusahaan ke pasar tertentu adalah untuk mencari keuntungan, sehingga berdasarkan fakta yang ada dimana terdapat pesaing baru yang masuk sangatlah tidak logis apabila pelaku usaha yang melihat keadaan suatu pasar dalam keadaan break even point (BEP) yang rendah mau masuk ke pasar tersebut dikarenakan dalam pasar tersebut sulit untuk mendapatkan keuntungan. ${ }^{22}$

Dengan demikian bila dilihat dari pernyataan para terlapor yang mengatakan terjadi perang harga menunjukan bahwa persaingan semakin ketat dan keuntungan atau profit yang semakin kecil untuk didapatkan. Namun fakta yang ada, dengan adanya pemain baru atau pelaku usaha baru yang memasuki pasar tersebut menunjukan bahwa itu bukanlah perang harga, dikarenakan masuk pemain baru menunjukan masih ada keuntungan dalam pasar tersebut. Majelis Komisi berpendapat bahwa perang harga yang "Berdarah-darah" (istilah yang digunakan oleh Investigator dan para Terlapor dalam menggambarkan kondisi yang merugi) bukan untuk mengundang pemain lain masuk melainkan untuk mematikan pesaingan karena kondisi "berdarah-darah" itu menunjukan pasar tersebut sudah tidak menarik. Dan Majelis Komisi berpendapat bila diputuskan untuk membuat kondisi yang "berdarah-darah" secara besama-sama, maka tindakan tersebut merupakan bentuk kesepakatan antar pelaku usaha yang semestinya bersaing. ${ }^{23}$

Setelah menganalisi bukti struktur, tentunya untuk melihat bukti komunikasi yang dilakukan oleh pelaku usaha atau para Terlapor. Dimana dalam kasus ini, Majelis Komisi menilai sewajarnya atau seharusnya surat penyesuaian tarif yang dikeluarkan oleh para Terlapor merupakan bentuk independensi kebijakan masing-masing Terlapor. Namun dalam fakta persidangan, dikeluarkannya surat penetapan tarif oleh para Terlapor tidak didasari atas independensi atau cost production masing-masing perusahaan melainkan berdasarkan momentum dan pergerakan harga yang diberikan oleh perusahaan pesaing. Sehingga dapat dipahami bahwa dikeluarkannya surat penyesuaian tarif dimana diakui sebagai momentum untuk menarik tarif bersamaan dengan pesaing membuktikan bahwa para Terlapor atau parusahaan pelayaran memiliki keuatan untuk dalam menentukan harga di pasar. Dimana para Terlapor memanfaatkan eksistensi dari tim marketing intelligence di

22 Ibid., hlm. 544

${ }^{23}$ Ibid., hlm. 545 
masing-masing perusahaan. Perlu dipahami bahwa marketing intelligence merupakan sebuat strategi yang dilakukan oleh pelaku usaha atau perusahaan yang bertujuan untuk memperoleh informasi dengan mengumpulkan data dan analisis suatu pasar. ${ }^{24}$

Bila melihat bukti komunikasi tentu saja perlu memahami makna komunikasi itu sendiri, berdasarkan Kamus Besar Bahasa Indonesia (KBBI) komunikasi adalah pengiriman atau penerima pesan atau berika antara dua orang atau lebih dimana pesan yang dimaksud dipahami semua orang. ${ }^{25}$ Berdasarkan keterangan Dr. Siti Anisah, S.H., M.Hum sebagai Ahli Hukum Persaingan Usaha dalam persidangan menjelaskan bahwa menurut Doktrin Oliver Black, salah satu jenis komunikasi adalah komunikasi umum. Bahwa komunikasi umum merupakan pengumuman kepada orang ramai atau memang ada publikasi kepada orang lain sehingga orang lain paham bahwa ada sesuatu yang diumumkan. ${ }^{26}$ Sehingga dalam kasus ini, surat penentuan tarif yang diumumkan merupakan bentuk komunikasi umum yang kemudian diterima oleh para perusahaan pesaing dengan menggunakan tim market intelligence sehingga menjadikan momentuk dan pergerakan harga tiap perusahaan untuk ikut mengeluarkan surat penetapan tarif jasa Freight Container rute Surabaya menuju Ambon.

Maka dengan dikeluarkannya surat penentuan tarif tersebut, Majelis Komisi melihat bahwa bentuk komunikasi yang dilakukan oleh para pelaku usaha atau para Terlapor dengan cara Price Signalling. Menurut Strategic Managemnt Theory: An Integrated Approach, Price Signalling adalah

"Price singnalling is the process by which companies increase or decrease product prices to convey their intentions to other companies and influence the way other companies price their products." ${ }^{27}$

Bila diartikan dalam Bahasa Indonesia bahwa Price Signaling adalah sesuatu proses yang dilakukan oleh perusahaan untuk menaikan atau menurunkan harga produk dimana bertujuan untuk menyampaikan niat mereka kepada perusahaan lain dan mempengaruhi cara perusahaan lain menentukan harga produk mereka. Sehingga dengan dikeluarkannya surat penyesuaian tarif freight container rute Surabaya menuju Ambon oleh semua pelaku usaha, adalah bentuk price signalling yang bertujuan memberi tahukan kepada pesaingnya

\footnotetext{
24 Mata Usaha, "Marketing Intelligence", diakses dari https://www.kompasiana.com/mata usaha/59d3262d0f64db3d407201b2/marketing-

intellegence\#: : :text=Marketing $\% 20$ intelligence $\% 20$ adalah $\% 20$ sebuah $\% 20$ strategi,diolah $\% 20$ dalam $\% 20$ sis tem $\% 20$ informasi $\% 20$ marketing., pada tanggal 4 Juni 2020, pukul 20:54 WIB.

25 Komunikasi. Kamus Besar Bahasa Indonesia (KBBI) Daring, 2016, diakses dari https://kbbi.kemdikbud.go.id/entri/Komunikasi, pada tanggal 4 Juni 2020, pukul 21:24 WIB.

${ }^{26}$ Putusan KPPU Nomor 8/KPPU-L/2018, Op.Cit., hlm 547

${ }_{27}$ Charles W.L. Hill dan Gareth R. Jones, Strategic Managemnt Theory: An Integrated Approach, edisi ke 10, Mason Ohio: South-Western Cengage Learning, 2015, hlm. 211.
} 
dan ikut menaikan tarif juga. Dengan demikian Majelis Komisi berpendapat bahwa price signalling merupakan bukti komunikasi diantara para pelaku usaha bahwa mereka "bersepakat" membuat harga tertentu.

Perlu dipahami bahwa dalam industry jasa freight container tidak ada keharusan atau perintah untuk membuat surat penetapan tarif/harga. Selain itu para terlapor juga tidak dapat menunjukan adanya surat penyesuaian tarif tahun-tahun sebelumnya sebagai rujukan untuk surat penyesuaian tarif tahun-tahun berikutnya. Sehingga patut diduga adanya surat penetapan tarif/harga tersebut membuktikan adanya komunikasi diantara masing-masing perusahaan pelayaran untuk "bersepakat" membuat harga tertentu.

Dengan demikian, adanya surat penyesuaian tarif yang dikeluarkan oleh para Terlapor atau keempat perusahaan pelayaran dimana dalam surat tersebut terdapat kemiripan dalam waktu penerbitan, waktu berlaku efektif, dan bersaran nilai harga/tarif. Membuktikan adanya komitmen yang seragam di antara para Terlapor yang ditunjukan dengan adanya komunikasi tidak langsung melalui price signalling yang dikirimkan antar perusahaan pelayaran untuk saling menyesuaikan harga kepada masing-masing konsumen. Sehingga dikeluarkannya secara bersama-sama dan serupa dalam isinya merupakan bentuk komunikasi para Terlapor untuk ikut serta dalam perjanjian penetapan harga dalam industry jasa uang tambang kontainer (freight container).

\section{B. Dampak Perjanjian Penetapan Harga yang Terjadi pada Industri Jasa Uang Tambang Kontainer (Freight Container) dalam Putusan KPPU Nomor 8/KPPU-L/2018}

Dalam suatu perkara persaingan usaha tidak sehat dan larangan praktek monopoli di Komisi Pengawas Persaingan Usaha (KPPU) umumnya digunakan 2 (dua) pendekatan, yaitu pendekatan per se illegal dan pendekatan rule of reason. ${ }^{28}$ Pendekatan Per Se Illegal adalah menyatakan setiap perjanjian atau kegiatan usaha tertentu sebagai illegal, tanpa pembuktian lebih lanjut atas dampak yang ditimbulkan dari perjanjian atau kegiatan usaha tertentu. Sebaliknya, pendekatan rule of reason adalah suatu pendekatan yang digunakan oleh lembaga otoritas persaingan usaha untuk membuat evaluasi mengenai dampak perjanjian atau kegiatan usaha tertentu, guna menemukan apakah suatu perjanjian atau kegiatan usaha tersebut menghambat atau mendukung persiangan. ${ }^{29}$ Dimana dalam

${ }^{28}$ Ni Putu Tryana Tresna Dewi dan I Ketut Westra, 2019, Kajian Yuridis Terhadap Perjanjian Penetapan Harga Dalam Putusan KPPU Perkara NNomor 14/KPPU-I/2014, Kertha Samaya: Journal Ilmu Hukum, Vol.7 No. 9, Fakultas Hukum Universitas Udayana, Bali, hlm. 11.

${ }_{29}$ Andi Fahmi Lubis, et. al, Hukum Persaingan Usaha Buku Teks, Cetakan II, Komisi Pengawas Persaingan Usaha, Jakarta, 2017, hlm. 66. 
Undang-Undang Nomor 5 Tahun 1999 tentang Larangan Praktek Monopoli dan Persaingan Usaha Tidak Sehat biasanya memuat kalimat yang sangat jelas untuk membedakan pendekatan apa yang digunakan dalam suatu pasal. Umumnya dalam pendekatan per se illegal dalam pasal-pasalnya menggunakan kata "dilarang", dan tanpa anak kalimat "yang dapat mengakibatkan". ${ }^{30}$ Sedangkan pendekatan rule of reason umumnya menggunakan anak kalimat "yang dapat mengakibatkan" dan atau "patut diduga". ${ }^{11}$

Bahwa dengan penjelasan tersebut pasal 5 ayat (1) Undang-Undang Nomor 5 Tahun 1999 tentang Larangan Praktek Monopoli dan Persaingan Usaha Tidak Sehat yang berisi "Pelaku usaha dilarang membuat perjanjian dengan pelaku usaha pesaingnya untuk menetapkan harga atas suatu barang dan atau jasa yang harus dibayar oleh konsumen atau pelanggan pada pasar bersangkutan yang sama.". Dengan demikian dapat dipahami bahwa pendekatan yang digunakan untuk menerangkan perkara ini adalah pendekatan per se Illegal. Namun dalam perkara KPPU Nomor 8/KPPU-L/2018 ini sulit untuk melihat adanya perjanjian yang menyatakan secara jelas para Terlapor mengikatkan diri untuk melakukan penetapan harga. Sehingga dengan adanya bukti langsung tersebut tidaklah perlu untuk melihat dampak apa yang akan terjadi, dikarenakan perbuatan yang dilakukan sudah sangat jelas dilarang dalam Undang-Undang Nomor 5 Tahun 1999. Namun dalam perkara ini menurut penulis patut dipelajar dikarenakan dampak yang terjadi akibat perjanjian penetapan harga yang dilakukan terlapor menjadikan awal mula dilakukannya pemeriksaan oleh Komisi Pengawas Persaingan Usaha.

Provinsi Maluku menyumbang Inflasi tertinggi di Indonesia pada bulan November 2017. Hal ini merupakan dampak dimana salah satu penyumbang inflasi di Provinsi Maluku khususnya Kota Ambon adalah dari sektor logisitk. Bahwa laporan tersebut berasal dari Laporan Bank Indoensia Provinsi Maluku dalam Rapat Tim Pengendali Inflasi Daerah (TPID) di Provinsi Maluku. Dimana KPPU diundang untuk rapat koordinasi oleh Tim Pengendali Inflasi Daerah (TPID) Provinsi Maluku untuk membahas kenaikan biaya sewa kontainer yang terjadi dim Maluku.

Menurt Kamus Besar Bahasa Indonesia (KBBI) inflasi diartikan yakni, "Kemerosotan nilai uang (kertas) karena banyaknya dan cepatnya uang (kertas beredar sehingga menyebabkan naiknya harga barang-barang."

${ }^{30}$ Yan Weilly Parsaoran Sinabariba, 2017, Tinjauan Yuridis Penetapan Harga (Price Fixing) Berdasarkan UndangUndang Nomor 5 Tahun 1999 tentang Larangan Praktek. Monopoli dan Persaingan Usaha Tidak Sehat (Studi Kasus Putusan Komisi Pengawas Persaingan Usaha Nomor 03/KPPU-I/2003), Jurnal Online Mahasiswa: Fakultas Hukum, Vol. 4, No. 2, Universitas Riau, Pekanbaru, hlm. 5.

31 Ranyta Yusran, Petingnya Prinsip "Per Se" dan "Rule of Reason" di UU Persaigan Usaha, diakses dari (https://www.hukumonline.com/klinik/detail/ulasan/lt4b94e6b8746a9/pentingnya-prinsip-per-se-danrule-of-reason-di-uu-persaingan-usaha/), pada tanggal 7 Juni 2020, pukul 17:08 WIB. 
Badan Pusat Statistik juga mendefinisikan yaitu:

"Inflasi adalah kecenderungan naiknya harga barang dan jasa pada umumnya berlangsung secara terus menerus dan dapat juga diartikan sebagai penurunan nilai uang terhadap nilai barang dan jasa secara umum."32

Maka dapat dipahami bahwa inflasi merupakan turunnya nilai mata uang dan naiknya harga barang dan jasa dalam periode waktu tertentu. ${ }^{33}$ Dimana salah satu dampak yang terjadi adalah masalah sosial akibat inflasi, diataranya adalah:

1. Menurunnya Tingkat Kesejahteraan Rakyat

Bahwa tingkat kesejahteraan masyarakat secara umum diukur dengan melihat daya beli masyarakat dari pendapatan yang diperolehnya. Dengan terjadinya inflasi maka harga barang yang ada akan naik namun pedapatan rakyat tidak ikut naik. Sehingga masyarakat akan kesulitan dalam membeli barang kebutuhan hidup, maka kesejahteraan rakyat pun akan menurun ${ }^{34}$.

2. Memburuknya Distribusi Pendapatan

Bila dilihat dari dampak terhadap tingkat kesejahteraan rakyat, sebenarnya dapat dihindari jika laju pertumbuhan tingkap pendapatan lebih besar dari laju inflasi. Bisa dipahami bahwa pihak atau orang yang memperoleh kenaikan pendapatan yang melebihi persentase dari laju inflasi akan mendapatkan keuntungan. Namun faktanya tidak semua orang dan hanya sedikit yang mempunyai kemampuan untuk meingkatkan pendapatannya melebihi laju inflasi jika dibandingkan dengan orangorang yang mengalami kerugian akbiat inflasi. Sehingga pola distribusi pendapatan menjadi tidak seimbang dan tidak merata. ${ }^{35}$

3. Terganggunya Stabilitas Ekonomi

Dalam hal stabilitas ekonomi, inflasi yang mengakibatkan harga barang yang tersu menaik membuat konsumen membeli barang dan jasa yang lebih banyak dari seharusnya. Dan bagi produsen, dengan harga yang terus naik membuat mereka untuk menunda mejual atau bisa dibilang "menimbun" untuk mendapatkan harga yang makin tingga dan keuntungan maksimal. Sehingga hal tersebut mengakibatkan penawaran barang jasa berkurang dan permintaan meningkat

${ }^{32}$ Badan Pusat Statistik, (https://www.bps.go.id/subject/3/inflasi.html\#subjekViewTab1), diakses tanggal 7 Juni 2020, pada pukul 23:02 WIB.

33 Imamul Arifin, Membuka Cakrawala Ekonomi, Pusat Pembukuan Departemen Pendidikan Nasional, Jakarta, 2009, hlm. 105.

${ }^{34}$ Ibid.

35 Ibid. 
dimana hal tersebut mempercepat laju inflasi dan kondisi ekonomi secara keseluruhan akan semakin buruk. ${ }^{36}$

Berdasarkan penjelasan diatas, salah satu dampak yang terjadi dalam kasus KPPU Nomor 8/KPPU-L/2018 selain berdampak pada inflasi yang terjadi, dampak yang dirasakan langsung oleh konsumen pelayaran setelah dikeluarkannya surat penyesuaian harga diantaranya adalah:

1. Terjadinya protes oleh pihak konsumen pengguna jasa EMKL dikarenakan adanya kenaikan harga yang sangat signifikan kepada perusahaan perlayaran, dimana konsumen tersebut terpaksa mengikuti harga tersebut dikarenakan mau tidak mau mereka harus mengirim barang

2. Naiknya biaya jasa EMKL, dimana persuahaan EMKL merespon surat kenaikan harga perusahaan pelayaran dengan mengirimkan surat kenaikan tarif yang ditujukan kepada konsumen akhir.

Maka dengan adanya kenaikan harga tersebut sangatlah berpengaruh kepada pengguna jasa freight container dikarenakan tidak adanya pilihan harga yang bersaing. Dengan demikian konsumen mau tidak mau harus mengeluarkan uang lebih, dan dapat dipahami bahwa barang-barang yang dikirim umumnya tidak untuk penggunaan pribadi namun untuk dijual di Kota Ambon. Bila kita tarik logikanya dalam perkaran ini, sangatlah wajar bila penjual di Kota Ambon menaikann harga jualannya dimana mereka harus membayar lebih dalam proses pengiriman barang mereka dari Surabaya menuju Ambon untuk menutup biaya pengirimannya. Hal tersebut juga berlaku oleh pihak Terlapor bila dasar mereka menaikan harga dikareanakan adanya kenaiakan cost production dimana salah satu penyumbang cost production tertinggi adalah bahan bakar minyak (BBM). Namun faktanya harga BBM tidak mengalami perubahan yang signifikan dimana hanya berkisar $3 \%{ }^{37}$ dan tidak terlalu signifikan mempengaruhi harga biaya kapal.Bisa diibaratkan bahwa cost product tersebut serupa dengan biaya yang harus dikeluarkan penjual yang menyulai barangnya menggunakan pengiriman barang melalui pelayaran. Dengan demikian kenaiakan harga jasa freight container tersebut sangan mempengaruhi harga barang yang masuk ke Kota Ambon dimana hal tersebut dapat memicu terjadinya inflasi di Kota Ambon.

Selain dampak yang dirasakan oleh konsumen, pelaku usaha juga merasakan dampak dikeluarkannya surat penyesuaian tarif. Dimana dengan dikeluarknya surat tersebut,

${ }^{36}$ Ibid.

${ }^{37}$ Putusan KPPU, Ob.cit, hlm 525. 
pelaku usaha mendapatkan pegerakan harga yang meningkat signifikan dimana pada bulan Januari 2017 hingga bulan Februari 2018 terjadi lompatan naik pergerakan harga di bulan September. Dan akibat dari perbuatan para Telapor berdasarkan keputusan Majelis Komisi, para terlapor terbukti secara sah dan menyakinkan melaggar Pasal 5 ayat (1) Undang-Undang Nomor 5 Tahun 1999. Dimana berdasarkan Undang-Undang Nomor 5 Tahun 1999, para telapor dikenakan sanksi tindakan andimistratif. Dalam Pasal 47 Undang-Undang Nomor 5 Tahun 1999 menjelaskan bahwa pelaku usaha harus membatalkan perjanjian penetapan harga, serta dikenakan denda serendah-rendahnya Rp. 1.000.000.000,00 (satu miliar rupiah) dan setinggi-tingginya Rp. 25.000.000.000,00 (dua puluh lima miliar rupiah).

\section{KESIMPULAN}

Berdasarkan penulisan yang telah dijelasakan diatas, dapat ditarik kesimpulan bahwa, tindakan yang telah dilakukan oleh keempat perusahaan pelayaran dalam industri jasa uang tambang kontainer atau freight container dalam rute Surabaya menuju Ambon yakni PT Tanto Intim Line, PT Pelayaran Tempuran Emas, Tbk, PT Meratus Line, dan PT Salam Pasific Indonesia Lines secara sah dan menyakinkan telah melakukan perjanjian penetapan harga. Dimana parjanjian penetapan harga yang dilakukan oleh terlapor dilakukan dengan cara mengeluarkan surat penetapan tarif, bahwa surat penetapan tarif yang dikeluarkan oleh keempat perusahaan pelayaran tersebut sangat serupa dalam isi, besaran harga, tanggal efektif, dan tanggal dikeluarkannya surat tersebut. Sehingga dalam pembuktian terjadinya perjanjian penetapan harga tersebut maka digunakannya bukti tidak langsung (circumstantial evidence) sebagai bukti petunjuk dapat membuktikan terjadinya perjanjian penetapan harga tersebut. Bahwa bukti tidak langsung (circumstantial evidence) ini menunjukan bukti komunikasi dan bukti ekonomi dimana dapat membuktikan terjadinya komunikasi secara tidak langsung untuk bersepakat dalam penetapan harga. Dan menunjukan analisi ekonomi atas perilaku pelaku usaha yang bertujuan untuk menghilangkan persaingan yang berdampak pada persaingan usaha tidak sehat.

Bahwa dengan dilakukannya perjanjian penetapan harga yang dilakukan oleh perusahaan pelayaran dalam industri jasa uang tambang kontainer atau freight container memiliki dampak yang besar. Dimana dikeluarkannya surat penetapan tarif tersebut berdampak sektor logistik menjadi penyumbang inflasi di Kota Ambon yang membuat Provinsi Maluku memberikan inflasi tertinggi di Indonesia. Serta dampak yang dirasakan langsung terjadi pada konsumen pengguna jasa uang tambang kontainer yang merasa 
terjadi perubahan harga yang sangat signifikan dan kemahal. Dimana mengakibatkan mereka mau tidak mau harus menerima harga tersebut dikarekana tidak ada pilihan lain. Dan bagi keempat perusahaan pelayaran tersebut, mereka mendapatkan pergerakan harga yang sangat signifikan dimana harga setelah dikeluarkannya surat tersebut memiliki nilai yang jauh lebih tinggi dengan nilai sebelum dikeluarkannya surat penetapan tarif tersebut.

\section{SARAN}

Penulis memandang perlunya Pemerintah untuk memperbaharui Undang-Undang Nomor 5 Tahun 1999 tentang Larangan Praktek Monopoli dan Persaingan Usaha Tidak Sehat guna memberlakukan bukti tidak langsung (circumstantial evidence). Dikarenakan Undang-Undang Nomor 5 Tahun 1999 tidak mengatur mengenai bukti tidak langsung (circumstantial evidence) dan KPPU hanya mengandalkan dari Peraturan KPPU Nomor 4 Tahun 2011 Tentang Pedoman Pasal 5 Undang-Undang Nomor 5 Tahun 1999. Hal itu dikarenakan pembuktian suatu tindakan perjanjian penetapan harga atau bahkan kartel sangatlah sulit perihal pembuktiannya dikarenakan tidak berwenangnya KPPU untuk menyita, menggeledah, dan menyadap.

Penulis berharap kepada Kementrian Perhubungan dalam hal ini Direktorat Jendaral Perhubungan Laut agar melakukan penataan dan pengawasan atas prilaku perusahaan pelayaran agar terjadi persaingan usaha yang sehat sehingga tidak ada pihak-pihak yang dirugikan akibat persaingan usaha yang tidak sehat.

\section{DAFTAR PUSTAKA}

\section{Buku}

Asmah, Hukum Persaingan Usaha "Hakikat Fungsi KPPU di Indonesia",Makassar: CV.Social Politic Genius (SIGn),2017.

Ahman. Eeng, Membina Kompetensi Ekonomi, Bandung: Grafindo Media Pratama,2017.

Arifin. Imamul, Membuka Cakrawala Ekonomi, Pusat Pembukuan Departemen Pendidikan Nasional, Jakarta, 2009.

Gilarso. T., Pengantar Ilmu Ekonomi Makro, Edisi Revisi, Kanisius, Yogyakarta, 2003.

Hill. Charles W.L., dan Gareth R. Jones, Strategic Managemnt Theory: An Integrated Approach, edisi ke 10, Mason Ohio: South-Western Cengage Learning, 2015.

Lubis. Andi Fahmi, et. al, Hukum Persaingan Usaha Buku Teks, Cetakan II, Komisi Pengawas Persaingan Usaha, Jakarta, 2017.

Nugroho. Susanti Adi, Hukum Persaingan Usaha di Indonesia: Dalam Teori dan Praktek Serta Penerapan Hukumnya, Jakarta: Kencana Prenada Media Group, 2014. 
Pohan. Chairil Anwar, Manajemen Pajak Korporat Kemaritiman: Berbasiskan Konsep dan Strategi Tax Planning, PT. Gramedia Pustaka Utama, Jakarta, 2019.

Rokan. Mustafa Kamal, Hukum Persaingan Usaha (Teori dan Praktiknya di Indonesia),Rajawali Pers, Jakarta, 2010.

Soekanto. Soerjono, dan Sri Mamudji, Penelitian Hukum Normatif. Raja Grafindo Persada. Jakarta, 2006.

Semaoen. Iksan, dan Siti Mariyatul Kiptiyah, Mikroekonomi, Malang: Universitas Brawijaya Press (UB Press), 2011.

Usman. Rachmadi, Hukum Persaingan Usaha Di Indonesia, Gramedia Pustaka Utama, Jakarta, 2004.

\section{Jurnal}

Dewi, Ni Putu Tryana Tresna dan I Ketut Westra. 2019, Kajian Yuridis Terbadap Perjanjian Penetapan Harga Dalam Putusan KPPU Perkara Nomor 14/KPPU-I/2014, Kertha Semaya: Journal Ilmu Hukum, Volume 7, Nomor 9. Universitas Udayana, Bali.

Sirait, Ningrum Natasya., Mahmul Siregar., dan Tetty Marlina Deborah Sihaloho. 2019, Penetapan Harga (Price Fixing) Sebagai Perjanjian yang Dilarang Dalam Undang-Undang Nomor 5 Tabun 1999 Tentang Larangan Praktek Monopoli dan Persaingan Usaba Tidak Sehat: (Studi Putusan KPPU Nomor 2/KPPU-I/ 2016 tentang Dugaan Price Handling oleh PT. Artha Samudra Kontindo dan PT. Sarana Gemilang. Trancsparency: E-Journal of Economic Law USU, Volume 1, Nomor 1, Universitas Sumatra Utara, Medan.

Sinabariba, Yan Weilly Parsaoran. 2017, Tinjauan Yuridis Penetapan Harga (Price Fixing) Berdasarkan Undang-Undang Nomor 5 Tahun 1999 tentang Larangan Praktek. Monopoli dan Persaingan Usaha Tidak Sehat: (Studi Kasus Putusan Komisi Pengawas Persaingan Usaha Nomor 03/KPPU-i/2003. Jurnal Online Mahasiswa: Fakultas Hukum Universitas Riau, Volume 4, Nomor 2, Universitas Riau, Pekanbaru.

Kadir. Abdul, 2006, Transportasi: Peran dan Dampaknya Dalam Pertumbuhan Ekonomi Nasional, USU e-Journals, Vol. 1, No. 3, Universitas Sumatra Utara, Medan.

\section{Peraturan Perundang-Undangan}

Undang-Undang Republik Indonesia Nomor 5 Tahun 1999 tentang Larangan Praktek Monopoli dan Pesaingan Usaha Tidak Sehat.

Undang-Undang Republik Indonesia Nomor 17 Tahun 2008 tentang Pelayaran.

Peraturan Komisi Pengawas Persaingan Usaha Nomor 4 Tahun 2011 tentang Pedoman Pasal 5 (Penetapan Harga) Undang-Undang Nomor 5 Tahun 1999 tentang Larangan Praktek Monopoli dan Persaingan Usaha Tidak Sehat.

\section{Internet}

Badan Pusat Statistik, https://www.bps.go.id/subject/3/inflasi.btml\#subjekViewTab1, (diakses tanggal 7 Juni 2020, pada pukul 23:02 WIB.)

Kapal Peti Kemas, https://id.wikipedia.org/wiki/Kapal peti kemas, (diakses tanggal 21 Februari 2020, pukul 17.00 WIB.) 
Kamus Besar Bahasa Indonesia (KBBI) Daring, bttps://kbbi.kemdikbud.go.id/entri/Komunikasi, (diakses tanggal 4 Juni 2020, pukul 21:24 WIB)

Mata Usaha, "Marketing Intelligence", diakses dari bttps:// www.kompasiana.com/ mata usaha/59d3262d0f64db3d407201b2/marketingintellegence\#: : :text $=$ Marketing $\% 20$ intelligence $\% 20$ adalab\%20 sebuab\%20strategi,diolah\% 20dalam\%20sistem\%20informasi\%20marketing., (pada tanggal 4 Juni 2016, pukul 20:54 WIB.)

Roza. Elviana, "Maritim Indonesia, Kemewahan Yang Luar Biasa", bttp://www2.kekp.go.id/artikel/2233-maritim-indonesia-kemewahan-yang-luar-biasa, (diakses pada tanggal 17 Februari 2020, pukul 09.51 WIB.)

Yusran. Ranyta, Petingnya Prinsip "Per Se" dan "Rule of Reason" di UU Persaigan Usaha, diakses dari bttps://wmw.bukumonline.com/klinik/detail/ulasan/lt4b94e668746a9/pentingnyaprinsip-per-se-dan-rule-of-reason-di-uu-persaingan-usahal, (pada tanggal 7 Juni 2020, pukul 17:08 WIB.) 